\section{Still no government reply to Canada's AIDS report}

\section{- Epidemic only two or three years behind US - Call for Cdn $\$ 35$ million per year on research}

\section{Washington}

THIS week the number of people with AIDS in Canada is expected to pass 2,000, giving it a per capita incidence of AIDS amongst the highest in the developed world, less than the United States and on a par with France (see below). But despite the severity of the problem, the Canadian government has not yet responded to the recommendations of a report on AIDS issued by the Royal Society of Canada over three months ago.

The report, entitled AIDS: A Perspective for Canadians, is summarized in a 30 page document and supported by a 400 page volume of background papers. It was begun in May of 1987 at the behest of the Canadian Department of Health and Welfare, which paid for the bulk of its cost through Canada's Federal Center for AIDS. Most of the recommendations do no come with price tags attached, but one of the exceptions is the area of basic research into AIDS: the Royal Society calls for Cdn $\$ 35$ million to be set aside per year on AIDS research, even though only Cdn $\$ 3.5$ million is being spent now. The Royal Society further says that the research efforts should include social and behavioural studies as well as biological and medical research, and should be coordinated by a national committee.

The chairman of the committee that prepared the report, Michel Chrétien, says the AIDS epidemic in Canada lags behind that of the United States by about two or three years, and that roughly 70 per cent of the cases are located in the cities of Vancouver, Montreal and Toronto, where one-fourth of the population lives. The distribution of cases among the population is also markedly different from that in the United States and most of Europe: over 80 per cent of those affected are homosexual or bisexual men, and less than one per cent are heterosexual intravenous drug abusers.

The report takes a liberal stance, opposing mandatory testing for HIV infection, and supporting anti-discrimination legislation, education on condom use, and dispensing clean needles to drug addicts to many of the recommendations are vague, vincial governments have control over healthcare expenditures.

The report stresses the "economics of prevention", and gives equal attention to the special healthcare needs posed by the prevent the spread of infection. Even so, in recognition of the fact that the pro-
AIDS epidemic, and to education and prevention activities.

Thirty-thousand Canadians are estimated to be infected with the human immunodeficiency virus (HIV), the virus causing AIDS, and eleven-thousand are projected to become ill by 1992 , with their treatment taking up about 2 per cent of the nation's total health budget. The report recommends investing $\$ 80$ million per year on AIDS education projects, and states that if the epidemic can be prevented from reaching US proportions, it will save Canada between $C d n \$ 2.5$ and

Alastair Clayton, the Director General of Canada's Federal Center for AIDS, says that his agency plans to spend $\$ 52$ million on AIDS education and prevention efforts out of its five-year budget of $\mathrm{Cdn} \$ 168$ million. Clayton, who is drafting the government's official response to the report, identifies public education as a top priority; surveys reveal that $30-60$ per cent of Canadians still believe that AIDS can be transmitted through environmental surfaces. Carol Ezzell - AIDS testing in the newborn, page 7. $\mathrm{Cdn} \$ 5$ thousand million.

\section{French government recognizes need for AIDS health campaign}

Paris

THE new French Health Minister, Claude Evin, has returned to his desk after the summer recess determined to intensify the nation's efforts to combat the spread of AIDS. Evin is alarmed by recent analyses that predict, if current growth rates are maintained, as many as 21,000 AIDS sufferers in mainland France by the end of 1989. With 3,628 cases at the end of March, France has perhaps the highest per capita incidence of AIDS outside the United States.

A cornerstone of Evin's change of pace is the appointment of a well-known public health specialist, Claude Got, to provide an in-depth assessment of AIDS in France by the end of September. Got is professor of anatomy and pathology at the Ambroise-Paré hospital in the western suburbs of Paris. Over the past ten years he has played a leading role in various government public health enquiries, gaining a reputation for his hard-headed approach. Last year he resigned from a High Commission on alcoholism when the minister for communications authorized beer advertisements on television despite demands that they should be banned.

The prominent role of French scientists in identifying the human immunodeficiency virus (HIV) undoubtedly contributed to a false hope that, by pouring money into medical research, the disease would be conquered. Now, says Evin, "it is obvious that we can no longer be content to wait for a vaccine or effective treatment to be available in order to confront the disease". Although the previous health minister, Michèle Barzach, has been praised for her measures to combat AIDS, her information campaigns were understated and have had little apparent effect on behaviour. In his remit, Evin asks Got to take a critical look at AIDS epidemiology, with the specific aim of guiding future public health campaigns.

Got's appointment coincides with the publication by the health department (Direction Générale de la Santé) of a demographic analysis of the known AIDS cases in France between 1978 and 1987. This study* shows that AIDS affects all socio-economic sectors of the French population, but that the geographical distribution of the disease, as well as its principal means of transmission, is changing.

While the Greater Paris area still has the highest proportion of AIDS sufferers (190 per million inhabitants), of which 73 per cent are homosexual and 7 per cent intravenous (i.v.) drug-users, this proportion of the national total has declined from 78 per cent in the late 1970 s and early 1980 s to 53 per cent in 1987 . This decline is probably due, say the authors of the study, to the increasing importance of needle sharing by drug-users as a means of transmitting disease. In south-east France, where drug abuse is a growing problem, the number of AIDS sufferers (125 per million inhabitants) has increased from 6 per cent of the national total in $1978-84$ to 17 per cent in 1987 . In this region, 35 per cent of AIDS sufferers are drug-users and 41 per cent homosexual.

With i.v. drug-users clearly emerging as the population in which AIDS is spreading most rapidly, Claude Evin may, after all, have to take action which last month he considered too controversial for the new government. His minister delegate for health was asked to resign just 9 days after being appointed precisely because of his radical proposals to control drug abuse and the spread of AIDS (see Nature 334. $461 ; 1988)$.
•Bulletin épidémiologique hebdomadaire, 8 August 1988. 